\title{
EU-Russia relations: a theoretical interpretation of Russia's perception of the European Union
}

Keywords: The EU-Russia relations, Russia, the European Union, perception, neorealism, neoliberalism, constructivism, social learning, social imitation

\begin{abstract}
For several decades the European Union was recognised as a major Russian partner, as cooperation with the EU had important political and economic effects on Russia. While these relations were based on common interests in such areas as energy, trade and cross-border cooperation, they also faced serious difficulties because of their different interpretation of values. A traditional explanation of Russia's attitude to the European Union was based on the theoretical assumptions of the rationalist approach. Neorealists tend to concentrate on the conflicts between the EU and Russia and describe it as a result of their struggle for spheres of influence over their common neighbourhood. In contrast, Neoliberals focused on EU-Russia cooperation and explained it as a problemsolving mechanism based on common interests and the necessity to solve common problems. While the rationalist approach fails to explain transformation of Russia's perception of the $E U$, constructivists demonstrate their capacity to explain the evolution of relations between the EU and Russia and the changes of Russia's policy towards the EU. This article studies the evolution of Russia's perception of the European Union within the context of EU-Russia relations and their possible theoretical interpretations. In order to examine Russia's perception of the EU, a constructivist theoretical framework is used with a special focus on imitation and social learning. The imitation process is illustrated by
\end{abstract}

* ORCID ID: https://orcid.org/0000-0002-8287-7687, Associate Professor at the Department of European Studies, School of International Relations, St Petersburg State University, Russian Federation. 
Russia's implementation of democratic norms and practices; the social learning concepts are used to evaluate political ideas used by Russia to show its vision of the EU and relations with the EU.

\section{Introduction}

The European Union was recognised by the Russian authorities as an important partner, and as being one of the major priorities of Russian foreign policy. In late 1990's its status was upgraded to 'strategic partner', which is an indica- tion of the EU's importance to Russia. In fact, relations between the EU and Russia developed with multiple 'ups' and 'downs', with their being periods of intense relations and periods where dealings between the two deteriorated. The abovementioned relations were based on common interests in such areas as: energy, trade and cross-border cooperation, but they also faced serious difficul-ties because of their different interpretation of values. The EU authorities often criticised Russia for its violation of democratic principles, while Russia reacted nervously to the growing European involvement in the post-Soviet region. The military activities of Russia in Chechnya and Georgia became a real challenge to EU-Russia relations and this almost undermined them, but it was possible to restore cooperation between the EU and Russia afterwards, and even to initiate new projects like Common Spaces, and the Partnership for Modernization. However since 2014, disagreements over the crisis in Ukraine have proved to be more difficult to overcome, and EU-Russia relations have been severely undermined, with only few areas of cooperation, including cross-border cooperation, research and education surviving. It is highly unlikely that the EU and Russia can return to their business-as-usual relations taking into account the substantial differences between the EU and Russia in terms of their interpretation of political situation in Ukraine, and their different approaches towards that state.

The traditional explanation of Russia's attitude to the European Union was based on theoretical assumptions of rationalist approach (neorealism and neoliberalism). Neorealists tend to concentrate on the conflicts between the EU and Russia and describe it as a result of their struggle for spheres of influence over their common neighbourhood, with the subsequent change of Russia's perception of the EU constituting the result of the EU's growing influence in the common neighbourhood. Neoliberals have focused on the cooperation between the EU-Russia, and explained it as a problem-solving mechanism based on their common interests and the necessity to solve common problems, but as the established institutions have failed to provide solutions, neoliberals face the problem of how to explain the deterioration of EU-Russia relations. From neoliberal point of view, Russia 
started to change its policy towards the EU because of the failure by international institutions to solve disputes. While the rationalist approach fails to explain the transformation of Russia's perception of the EU, constructivists demonstrate their capacity to explain the evolution of EU-Russia relations and the changes of Russia's policy towards the EU.

In this article, I will examine how Russia's perception of the European Union could be examined from the perspective of neorealism, neoliberalism and constructivism, and then evaluate the explanatory capacities of these approaches. I will argue that the evolution of Russia's attitude towards the EU can be explained best by employing the constructivist theoretical framework. It is Russia's experience of social learning and imitation that determined the development of EU-Russia relations. I would like to show how constructivism can help to explain Russia's perception of the EU and the change in EU-Russia relations.

\section{Theoretical approach: rationalist explanation}

Academic discussion about EU-Russia relations has been largely determined by the rationalist approach (neorealism and neoliberalism). It has enabled researchers to examine both cooperative and conflictual forms of interaction between the EU and Russia.

Neorealism with its focus on interests, power, the balance of power, spheres of influence and security, was particularly popular among experts in Russian foreign policy who usually describe Russia as a traditional nation state willing to ensure its security, protect its sovereignty and use a policy of balancing towards other actors. Russian foreign policy is often perceived as neorealist in terms of its interpretation of international relations, the international environment, and the rationality of other actors, its own national interests and foreign policy objec-tives. Russia is an interest-oriented international actor, its external activities are determined by its interests, it expects other actors also to take decisions in order to maximize their interests ${ }^{1}$. Consequently, dealing when with the EU, Russia is concerned about the interests represented by the EU and their potential influence on Russia. In fact, the complicated institutional framework and decision-making procedures of the EU and the balance between the national interests of member states and its supranational interests make it difficult for the third countries, like

\footnotetext{
1 A. Sergunin, "Vostochnoe partnerstvo" $i$ evropeiskaya bezopasnost, «Evropeiskaya bezopasnost: sobytia, otzenki, prognozy» 2009, Vol. 18; A.A. Sergunin, V.G. Tikhonov, "Vostochnoe partnerstvo" i rossiyskye interesy na Kavkaze, «Izvestia visshikh uchebnyh zavedeniy. Severo-Kavkazskyi region. Ser. Obschestvennye nauki» 2010, Vol. 4 (158), pp. 35-39.
} 
Russia, to understand how the EU's interests are determined by the decisionmakers.

Russia is also highly suspicious about the potential influence of the US on the EU's policies. Although the fear that the EU could partly represent US interests is driven by a misunderstanding of the EU decision-making procedures, and an exaggeration of the US influence has in Europe, the expectation of strong political links between the EU and the US could be explained within neorealist framework which underestimates institutional constrains, emphasizes security issues, which dominate the political agenda, and indicates that actors with stronger military power can transfer their power into political influence. The fear that the US could exercise its influence over the EU via NATO has led to Russia's attempts to make a clear distinction between the EU and NATO, and Neorealists often compared Russia's relations with the EU and NATO. In contrast to NATO, which has raised Russia's security concerns and fears because of the perception of it being a major military alliance that is moving closer towards its borders, the EU was perceived as a relatively harmless alternative to preserving security in the region. ${ }^{2}$ Relations with the EU were largely seen in terms of Russia's security interests and as an opportunity to provide a counterbalance to NATO, and undermine its influence in Europe. The EU and NATO were evaluated depending on their relative power and influence on Russia's security. While Russia strongly opposed the enlarge- ment of NATO into Eastern Europe, which it perceived as a strategic and security challenge. Russia at first demonstrated a neutral reaction to the EU's Eastern enlargement, which was mainly examined in terms of the economic consequences for Russian businesses in the accession countries and the technical problems connected with the Kaliningrad region. Russia also supported the development of the EU military capabilities in the form of the European Security and Defence Policy (ESDP). Some researchers indicated that the strengthening of the military capabilities of the EU could turn it into an alternative to NATO and undermine NATO's role in the region ${ }^{3}$. But this attempt to balance NATO with the aid of the EU failed, as the EU did not want to duplicate NATO and strengthened its cooperation with the alliance.

The European Neighbourhood Policy (ENP) raised new concerns for Russia about the EU's interests in the countries that neighboured Russia's borders. This reinforced the neorealist research agenda, as they referred to Russia's nervous

${ }^{2}$ S. Karaganov, Russia, Europe and New Challenges, «Sovremennaya Evropa» 2003, Vol. 1 (13), pp. 8-16.

${ }^{3}$ N.S. Revenko, Sotrudnichestvo mezhdu Rossiei i Evropeiskim soyuzom v voenno- politicheskoi oblasti: sovremennoe sostoyanie $i$ perspektivy razvitiya, [in:] Partnerstvo Rossii $i$ Evropeiskogo soyuza posle rasshireniya: strategicheskoe planirovanie i povsednevnaya realisatsiya, Sankt-Peterburg 2004. 
reaction to the growing activities of the EU in the post-Soviet region, and Russia's attempts to re-establish its own influence in the region using various instruments including energy resources and integration projects. Thus the EU became a competitor for Russia, as its intensified cooperation with the post-Soviet states became a challenge for Russia's influence over its near neighbours ${ }^{4}$. In addition, new EU activities in the region and the introduction of the Eastern Partnership (EaP) resulted in further conflict between the EU and Russia, and their competition for allies in the region turned international relations there into a 'zero-sum game'. The post-Soviet states had to choose between strengthening relations with Russia, or intensified cooperation with the EU. Conflict in Georgia in 2008, and then in Ukraine further supported the theoretical assumptions of neorealism, which lead to the growing popularity of this approach among researchers, particularly in Russia.

Neoliberalism also implies the rationality of actors and their concerns about interests. But, in contrast to neorealism, it focuses mainly on cooperative behaviour, and indicates the mutual benefits that result from international cooperation. The neoliberal theoretical framework enabled researchers to explain the cooperation between the EU and Russia as well as common institutions that they created to facilitate this cooperation. Neoliberals have argued that the common interests that EU and Russia share should necessitate cooperation in order to benefit from this cooperation and to solve common problems. They examine the institutional and legal basis of EU-Russia relations, and this approach enabled the study of the general development of EU-Russia cooperation and sectoral cooperation in such areas as energy, trade, cross-border cooperation, etc.

Neoliberals describe international cooperation as an opportunity for actors to minimize transaction costs and combine their resources to solve common problems: "The common interests were indeed the locomotive that drove them together" 5 . This approach implies that EU-Russia relations were determined by common interests, and the decision to develop cooperation in certain sectors and to upgrade the framework of cooperation was made in accordance with the common interests of the EU and Russia. Multiple reasons were suggested for their common interests, including the transnational nature of international relations, interdependence, and limited individual resources and the necessity to combine resources.

The transnational nature of international relations makes it impossible for actors to solve certain problems on their own, and they have to cooperate in

\footnotetext{
${ }^{4}$ A. Zagorski, Russia and the shared neighbourhood, [in:] D. Lynch (ed.), What Russia Sees, Chaillot Paper No. 74, Paris: EU Institute for Security Studies 2005, pp. 61-78.

${ }^{5}$ N. Zaslavskaya, The European Union and Russia, [in:] J.-U. Wunderlich, D. Bailey (eds.), The European Union and Global Governance: A Handbook, London and New York, Routledge 2011, pp. 274-284.
} 
such areas as environment and migration. Moreover, the geographic proximity of the EU and Russia and their long common border necessitates the need to solve transnational problems together ${ }^{6}$. Energy could be described as an area of interdependence between the EU and Russia, and of course, energy cooperation is highly important both for the EU and Russia. The EU is interested in Russia's energy resources; while Russia benefits from having a stable and reliable consumption of its energy resources in Europe. The importance of energy cooperation required the creation of a sectoral institutional framework 'energy dialogue' (Permanent Partnership Council on energy, thematic working groups, subgroups, Energy Industry Steering Group). Neoliberals have examined various issues of energy cooperation, including the major concerns of the EU and Russia, the institutional framework and its transformation, and the levels of cooperation between the EU and Russia7.

In some cases, actors have limited resources and in order to ensure the efficiency of certain activities, they need to combine resources with other actors. This logic determines cooperation between the EU and Russia in such areas as security, counter-terrorist activities and space cooperation ${ }^{8}$, and coordinating their activities enables them to maximize the efficiency of their actions. Of course, political cooperation is usually the most vulnerable to various challenges. Focus on common interests reflected Russia's concerns. It benefited from the development of cooperation with the EU, it realized the importance of a common institutional framework, facilitated cooperation, arranged political consultations, and discussed conflicts. The institutional framework provided Russia with an opportunity to hold regular consultations with its EU counterparts, thus consolidating "the rapprochement between the European Union and Russia"9.

However, since 2014 EU-Russia cooperation was undermined and the institutions failed to face new challenges, and thus creating theoretical problems for neoliberalism. Apparently, the institutional framework was only capable of operat-

6 N.B. Kondratieva, Rossiya-ES: Transgranichnoye sotrudnichestvo vne kon'uktury, «Sovremennyaya Evropa» 2014, Vol. 60 (4), pp. 33-47; K. Koch, Region-Building and Security: The Multiple Borders of the Baltic Sea Region After EU Enlargement, «Geopolitics» 2015, Vol. 20 (3), pp. 535-558.

${ }^{7}$ I. Pashkovskaya, Energeticheskaya politika Evropeiiskogo Soyuza v otnoshenii Rossii, «Centre of Euro-Atlantic Security: Analytical Reports» 5 (29), Moscow: MGIMOUniversity 2015, pp. 14-18; T. Romanova, EU - Russia Energy Cooperation: Major Development Trends and the Present State, «Baltic Region» 2013, Vol. 3, pp. 4-13.

8 D.A. Danilov, Obshchee prostranstvo vneshnei bezopasnosti Rossii $i$ ES: ambitsii i realnost, «Mirovaya ekonomika i mezhdunarodnye otnosheniya» 2005, Vol. 2, pp. 35-47; P.A. Kalinichenko, A.Kh. Mitrokhina, Legal Bases of Mutual Relations Between Russia and the European Union in the Field of Space Exploration, «Aktualnye problemy rossiyskogo prava» 2018, Vol. 90 (5), pp. 176-184; D. Lynch, Russia's strategic partnership with Europe, «Washington Quarterly» 2014, Vol. 27 (2).

${ }_{9}^{9}$ Partnership and Cooperation Agreement, Art 6. 
ing when the EU and Russia were willing to cooperate, but it was unable to act as a framework for consultation, and to solve serious conflict that was the result of the Ukrainian crisis. The limited capabilities of the institutions have raised concerns about the neoliberal vision of institutions as a framework, not only to strengthen cooperation, but also to discuss and solve problems. The deteriorating relationship between the EU and Russia have raised also concerns about another neoliberal assumption: the importance of common interests and their influence on international cooperation. The EU and Russia demonstrated that they have other priorities, which were more important than the potential benefits from their cooperation.

A rationalist approach provides an explanation for the major tendencies of EURussia relations; it has certain advantages and disadvantages. Neorealism bet- ter explains the conflicts between the EU and Russia. Neoliberalism describes the rationality behind their cooperation. However, rationalists have failed to explain the transformation of Russia's policy towards the EU.

\section{Theoretical approach: constructivist explanation}

Constructivism, with its theoretical assumptions, helps us to fill in those gaps that were neglected by rationalism. Its concepts of socialization, imitation and social learning enable us to understand the transformation of Russia's approach to the EU. Russia's vision of the EU was transformed throughout its socialization with the EU. Its interactions with the EU have shaped Russia's expectations and have influenced its European policy.

I think that constructivism enables us to go beyond the explanation of actors' behaviour by evaluating the role of social interaction. Its interpretation of the constructed nature of international relations, and its focus on ideas and norms provide researchers with new opportunities to interpret the evolution of identities that result from social interaction ${ }^{10}$. Social constructivism, which was introduced by Alexander Wendt, describes how identities are formed and transformed within the process of socialization. On the one hand, throughout socialization actors imitate norms exercised by successful actors. This process of imitation is based on the idea that less successful actors expect that with the adoption of certain norms they can ensure successful development, with the influence of successful actors being similar to magnetism. Their positive experience is like a magnet that attracts other actors and they believe that following them, implementing

${ }^{10}$ E. Adler, Seizing the Middle Ground: Constructivism, «World Politics in European Journal of International Relation» 1997, Vol. 3, pp. 319-363; A. Wendt, Social Theory of International Politics, Cambridge University Press 2007. 
their norms, practices and regulations it is possible to achieve similar success. Imitation implies that norms facilitate the development of actors. As a result of the imitation successful norms are projected, as more actors get involved in the process. Imitation facilitates cooperation, as an increasing number of actors share similar norms. Due to the political and economic success of the EU member states, the European Union is usually perceived as a successful actor. Its norms are recognized as best practices. Less successful actors often expect that fol- lowing the EU experience and practices, adopting its norms would eventually ensure similar results. Imitation of the European norms enables the EU partners to cooperate with it.

On the other hand, through socialization, actors learn about their identity, themselves and other actors. Social learning refers to the formation of actors' identities as a result of interaction. Dealing with other actors, they determine their own roles and suggest roles for those other actors. Roles and perceptions are not fixed; they are transformed during social interaction. The reaction of other actors to the suggested roles influences the further transformation of identi- ties. These suggested roles and the reaction to them is determined by the actors' perception or misperception of each other. Actors evaluate their expectations and the eventual reaction of others. Social learning enables actors to better under- stand themselves and their identities in the context of interaction with other actors. Perceptions demonstrated by others also influence actors' identities. An examination of social learning helps researchers to study the evolution of actors' identities and the perception of others. By interacting with others, actors can strengthen their own identity, create a common identity, and strengthen conflicting identities.

Constructivists examine the consequences of social learning for identities formation. They demonstrate how, on the basis of the concept of social learning, it is possible to research actors' identities. They indicate aspects of social learning that determine the evolution of identities, and the necessity to adjust their approach towards other actors depending on their self-identity and perception of others. They examine the conditions that determine the potential consequences of social learning for actors' identities. Wendt described several issues that should be taken into account when examining the influence of social learning on identity formation: an actor's significance and power. An actor's significance is determined by the attitude of other actors. During social interaction, actors evaluate the significance of other actors to them. It is a relative significance, based on the comparison of significance of different actors. Depending of their relative significance, actors would be more or less sensitive to the perceptions expressed by other actors. In case of more significant actors usually 'interaction proceeds smoothly', as oth- ers prefer to accept the roles that are suggested for them and share the norms of 
significant actors ${ }^{11}$. Of course, for less significant actors, it is difficult to persuade others to accept their suggested roles and share their norms. An actor's power is another issue influencing social learning. Constructivists use the definition of power suggested by Deutsch: 'an ability not to learn' ${ }^{12}$. Power determines the capability of actors to influence others' perceptions and interpretations. More powerful actors are more influential in terms of their capability to ensure certain perceptions of the others; less powerful actors have limited opportunities to influence the perceptions of the others.

Turning to EU-Russia relations, it is possible to examine the interaction between the EU and Russia on the basis of constructivist theoretical assump- tions; evaluate how their identities and perception of each other were determined by social interaction. A constructivist theoretical framework enables us to move beyond the traditional rationalist explanations and study the evolution of identities and perceptions as a result of social interaction. Constructivist concepts of imitation and social learning help us to understand the evolution of Russia's identity in the process of its interaction with the European Union and eventually the evolution of Russia's attitude to the European Union.

\section{Russia's perception of the EU: imitation and learning}

Let's examine whether Russia's policy towards the EU could be described by the constructivist concepts of imitation and learning. According to the imitation concept, Russia should be influenced by the EU because of its success. It should perceive the EU as a role-model that demonstrates its successful experience. It also should expect that following the European norms and regulations it would eventually succeed. I argue that interacting with the EU, Russia made an effort to adopt European practices and regulations, including democratic principles and some sectoral practices like technical standards and environmental norms.

The discussion about the implementation of democratic norms and practices in Russia could illustrate the process of imitation in EU-Russia relations. In the 1990 's they were considered as the basis of the cooperation between the EU and Russia. Democratic principles were an important part of the 'shared common values' which were determined by the Partnership and Cooperation Agreement (PCA). However, it was predominantly the EU that was concerned to ensure that its Russian partner shared its devotion to democratic norms and practices. In addition, the EU and Russia had different perception of democratic norms and

${ }^{11}$ A. Wendt, Social Theory of International Politics ..., pp. 328-329.

12 Ibidem, p. 331. 
their importance for EU-Russia cooperation. While the EU always insisted on reference to democratic norms and principles as the basis of cooperation, Russia was more concerned about the economic aspects of cooperation. Russia agreed to imitate the EU's support of democratic norms: 'importance of the rule of law and respect for human rights, particularly those of minorities, the establishment of a multiparty system with free and democratic elections...'13.

In early 1990's, Russia was struggling to recover, after an economic and political crisis. It perceived the EU as a successful international actor and an important economic partner. The EU's norms and practices were seen as a recipe to restore the Russian economy and political system. Its leaders, including President Yeltsin and Foreign Minister Kozyrev, who were in favour of close relations with the West, initiated pro-Western political reforms in Russia and recognized common values with the European Union. The political reforms in Russia were based on democratic norms and practices, and Russia started to follow the European track in terms of its political practices. However, by mid 1990's President Yeltsin appointed a new Foreign Minister Primakov, who was famous for his sceptical attitude to the West. His appointment demonstrated that the Russian authorities were reconsidering their policy towards the West, including the European Union. Indeed, Russia started to act more critical towards the West, and its values, which raised doubts about Russia's devotion to having 'shared common values' with the EU. On the one hand, the political reforms were continued, democratic institutions were established, democratic norms and procedures were politically supported and legally adopted; on the other hand, there were multiple cases when the democratic norms were violated. A military confrontation between the President and the Parliament (in October 1993), and military operations in Chechnya to confront separatism there (1994-1996 and 1999-2000) demonstrated different interpretation of the values in the EU and in Russia. These growing contradictions over values hindered the further development of EU-Russia cooperation. In late 1990 's, their different perceptions of democratic values were demonstrated in the Russian and EU strategic documents dedicated to the prospects of EU-Russia cooperation. While the EU Common Strategy towards Russia indicated the EU's concern about the prospects of democratic reforms in Russia, the Russian Strategy towards the EU paid little attention to importance of democratic reform in Russia for the EU-Russia relationship. The EU wanted to see Russia as a stable, open and pluralistic democracy' ${ }^{14}$. The Russian document ignored the European concerns about civil society, independent NGO's, and media. The only democracy-related issue that was mentioned in the Russian strategy was the possibility to use the EU

\footnotetext{
${ }^{13}$ Partnership and Cooperation Agreement, 1994.

${ }^{14}$ Common strategy of the European Union on Russia, 1999.
} 
experience to support, "further construction of a democratic rule-of law State" in Russia ${ }^{15}$. As a result, any democratic transformation was limited to reform of state institutions, and the implementation of the principle of the rule-of-law. EU concerns about the violations of democratic norms were neglected. After Russia resumed its military operation in Chechnya in late 1990's, EU officials became more critical about the political and judicial practices in Russia, and increased pressure on the Russian authorities by indicating various problems with the implementation of democratic principles and neo-authoritarian tendencies in Russia.

In response to the EU's growing criticism of Russian political and judicial practices, Russian officials formulated the concept of 'the sovereign democracy', which implied the influence of a national context on the implementation of democratic norms. In 2005, during the US-Russian summit in Bratislava, President V.Putin confirmed Russia's decision to strengthen democracy. He agreed that the major democratic principles should be implemented and essential democratic institutions should exist as it is required in a contemporary democratic society. However, he also mentioned that these democratic institutions should correspond to the Russian political and societal traditions. Putin's assistant Vladislav Surkov further elaborated this idea and formulated 'the sovereign democracy' concept, which described a state based on democratic principles, but free from the influence of third countries, sovereign within its borders and based on its national traditions ${ }^{16}$. This was a clear indication that Russia had decided to limit the democratic norms and practices. It was ready to imitate only those norms that it considered crucial for a democratic state, but it secured the possibility to adjust them in accordance to Russia's history and traditions. This lack of interest in further imitation of the European norms could be explained by Russia's doubts about EU's practices, and their potential effect on Russia. EU norms and practices did not guarantee similar political and economic success, which was a crucial aspect of the imitation process, and thus Russia's perception of the EU as a rolemodel was undermined. Another important fact that influenced Russia's attitude to the EU norms was the economic success that Russia enjoyed in the mid 2000's, with GDP growing and a decrease in the rate of inflation. This economic success was perceived as an indication that Russia could restore its international status without following the EU track by implementing European practices. Therefore, the EU experience became less attractive and less motivating for Russia. While

15 The Russian Federation Middle Term Strategy towards the EU (2000-2010), 1999.

${ }^{16}$ M. Lipman, Sovereign Democracy, «Washington Post» 15 July, 2006; V. Surkov, 'Suverenitet - eto politichesky sinonim konkurentosposobnosti' ('Sovereignty is a political synonym to competitiveness'), public speech, 7 February, 2006 http://surkov.info/stenogrammasuverenitet-\%e2\% 80\%93-eto-politicheskij-sinonim-konkurentosposobnosti-chast-2/ (05.11.2019). 
imitation of the EU norms lost its importance, Russia revealed other options to achieve success.

Today, Russian officials seldom refer to the sovereign democracy concept, but they do use its major assumptions when they argue that Russia is a state based on democratic principles that reflect Russian cultural traditions. They no longer demonstrate support for having shared common values with the European Union. On the contrary, they actively criticise European norms by emphasizing the difference between conservative Russian values and liberal European val- ues. The Russian authorities try to shift the political discourse on values from democracy-related issues to family-related issues. They argue that the Russian society focus on traditional family values is in contrast to the EU, with its reconsideration of families. When criticising EU values and practices, Russian officials demonstrate an unwillingness to imitate EU norms.

The transformation of Russia's policy towards the EU could also be examined by the process of social learning, which describes how actors involved in social interaction learn about themselves and others, form and transform their identities and attitude towards other actors. By interacting with the EU, Russia learned about its partner and reacted to the role suggested to it by the European Union. This social learning led to the evolution of Russia's attitude to the EU. The Russian authorities examined their experience and started to formulate political concepts reflecting their vision of the EU-Russia relations, including Russia's and EU's roles in these relations.

With the help of discourse analysis, I have examined the narratives used by Russian officials (presidents, prime-ministers, foreign ministers and permanent representatives to the EU) and identified the political concepts that they articulated. These political concepts reflect Russia's vision of its relations with the EU, its role in these relations and the role of the European Union. I assumed that the shift from one political concept to another indicates changes of Russia's attitude to the EU as a result of social learning. As a result of my research, I have determined five political concepts. Two of them are antagonistic concepts: Europeanization and New Dividing Lines. They describe two contradictory scenarios of EU-Russia relations and two opposite sets of roles for the EU and Russia. The Europeanization concept emphasized the prospect for a cooperative EU-Russia relationship, while the New Dividing Lines concept concentrates on the conflictual nature of relations between the EU and Russia. The other three concepts conceptual- ize different frameworks for cooperation between the EU and Russia: Strategic Partnership, Common Spaces and Wider Europe. They prescribe different scales of cooperation and roles for the EU and Russia.

Traditionally, the concept of 'Europeanization' was used as a reference to the EU's influence on the national level of policy-making leading to a rearrange- 
ment of thee various activities within a nation state to the requirements of the European Union. In fact, it is a multifaceted concept, which implies both the influence of EU politics on national politics, and the influence of EU member states on EU Policies. Although, this concept usually refers to member states, it also could be used to describe the EU influence on third states, which hardly can try to influence the EU in return. Russian policy-makers and experts borrowed this concept and suggested several new interpretations of it. Their interpreta- tions demonstrated Russia's concerns about the EU influence on Russia and its consequences:

1) Europeanization as a projection of European norms and values, economic standards and democratic principles ${ }^{17}$

2) Europeanization as modernization 18 ;

3) Europeanization as a priority of European dimension of Russia's foreign policy ${ }^{19}$

4) Europeanization as further cooperation on the basis of European cultural heritage shared by the EU member states and Russia ${ }^{20}$.

Despite these different interpretations, the Europeanization concept demonstrates a positive vision of the EU and its influence on Russia. It emphasizes Russia's similarities with other European nations and focuses on common knowledge shared by both the EU and Russia.

The concept of 'Strategic Partnership' was officially supported by the EU and Russian authorities. It was introduced in 1999 by the EU in its Common Strategy on Russia and outlined the prospects for further cooperation between the EU and Russia. It was an important indication of the new level of relations. In terms of its content, it is a relatively flexible concept to describe a high level of cooperation and a long-term agenda without reference to specific instruments and frameworks. The major assumption of this concept was that the partnership between the EU and Russia was based on strategic interests, so they had to intensify their cooperation to solve various problems, maintain stability, and ensure security in Europe and around the world. This focus on common interests corresponded to Russia's rational vision of international relations. Russian officials regularly referred to

${ }^{17}$ T. Bordachev, A. Moshes, Russia: End of Europeanization, «Global Affairs» 7 April 2004, http://globalaffairs.ru/number/n_2855 (01.10.2019); V. Mau, 'Strategic Europeanization', VIPerson, 7 April (2000), http://viperson.ru/articles/vladimir-may-strategicheskayaevropeizatsiya (01.10.2019).

${ }^{18}$ E. Krivyakina, President Medvedev's first 100 days in Office, «KP» Aug 14, 2008, http:// www.kp.ru/daily/24146.4/363261 (01.10.2019).

19 T. Shadrin, Medvedev poidet na vtoroi presidentsky srok, «Week Journal» March 2, 2011, http://weekjournal.ru/politics/28246 (05.11.2019).

20 V.V. Putin, Speech at Reichstag, Berlin, 25 September, 2001, http://en.kremlin.ru/events/ president/transcripts/21340 (01.10.2019). 
strategic partnership, to common interests, to the necessity to make strategic partnership more efficient, to its long-term ambitions and successful future ${ }^{21}$. When Russia faced problems dealing with the EU, Russian officials argued that these challenges, "will test the quality of our strategic partnership", e.g., in case of Eastern enlargement ${ }^{22}$. The strategic partnership concept implied an equal partnership between the EU and Russia. It was a highly significant issue for Russia as a symbol of its international role and an indication that its interests would be taken into account. Russian authorities supported this concept as it reflected major Russian concerns, as they believed that cooperation based on strategic interests in various spheres would allow for the overcoming of potential problems and conflicts.

'The Common Spaces' concept constituted an instrument for strengthening the strategic partnership by provided a framework for the cooperation between the EU and Russia in various spheres. It was mentioned in the EU Country Strategy Paper on Russia ${ }^{23}$, with each common space supposed to ensure the cooperation in a specific area: starting from economic cooperation with integrated market to security and cultural cooperation. This concept reflected Russia's positive perception of the European Union, as Russia was interested in intensifying its cooperation with the Europeans in various sectors. From the Russian point of view, the common spaces concept was the EU recognising the importance of its relations with Russia. The Russian authorities compared this concept with the European Neighbourhood Policy (ENP) in terms of the roles given to the EU neighbours. In 2003, Russia perceived the ENP and common spaces as two alternative frameworks for cooperation with the EU. While the ENP was an asymmetric EU-led project, the common spaces was a common project of equal partners 24 .

'The Wider Europe' concept was an EU concept that was suggested together with the ENP. Although the document described the geographical scope of the New Neighbourhood, and not Wider Europe, it was implied that Wider Europe would cover the territory of an enlarged European Union, the Western Balkans that were involved in a Stabilisation and Association Process, as well as their new neighbours, including Russia, Ukraine, Moldova, Belarus, and the Southern

21 D. Medvedev, Joint Press Conference following the Russia-European Union Summit, Khanty-Mansiysk, 27 June 2008; V.V. Putin, Press Conference Following the RussiaEuropean Union Summit, Moscow, 21 May 2004.

22 V.V.Putin, Statement for the Press and Answers to Questions at a Press Conference after the Russia-European Union Summit, Moscow, 29 May 2002.

${ }^{23}$ European Commission, Country Strategy Paper 2007-2013: Russian Federation, Brussels 2007.

${ }^{24}$ V.A. Chizhov, Speech at the conference 'Russia and EU Common Foreign Policy Aims and Challenges, Berlin, 23 February 2004, http://www.mid.ru/en/evropejskij-souz-es/-/ asset_publisher/6OiYovt2s4Yc/content/id/483854 (05.11.2019). 
Mediterranean countries. For the EU, Wider Europe was a framework for regional cooperation, to combine efforts aimed at tackling trans-boundary threats, 'to avoid drawing new dividing lines in Europe and to promote stability and prosperity within and beyond the new borders of the Union'25. For Russia, Wider Europe concept was perceived separately from the ENP and it was believed that it could provide serious advantages. While the Russian officials demonstrated a lack of interest in the ENP, surprisingly they expressed support for the Wider Europe concept. In Russia the concept was reconsidered according to its interests, as the Russian interpretation of the concept was close to Gorbachev's 'Common European Home'. Wider Europe was perceived as a pan-European framework, which would facilitate cooperation on the regional level and enable the coexistence of various forms of subregional cooperation ${ }^{26}$, "a Greater Europe without dividing lines"27. Depending on the particular integration projects it could become a framework for a single continental market ${ }^{28}$ or common economic and humanitarian space from the Atlantic to the Pacific ${ }^{29}$. This concept perfectly corresponded to the Russian concerns about, "truly unified Europe without dividing lines" 30 . Russia elaborated this concept, with them suggesting new objectives that could be implemented or based on it, and it is interesting that Russian officials used a concept suggested by the EU. This concept initially reflected Russia's long-term goal of cooperation with the EU, on the basis of equal partnership and strategic interests. After 2014, this concept was applied by the Russian authorities as an indication of the non-cooperative behaviour of the West. The Russian Minister of Foreign Affairs, Lavrov, insisted that, "Russia is open to the widest possible cooperation with its Western partners" and, "we are not seeking confrontation with the United States, or the European Union, or NATO"31. Of course, this rhetoric of the Russian authorities ignored root contradictions that undermined EU-Russia relations.

${ }^{25}$ European Commission, Wider Europe - Neighbourhood: A New Framework for Relations with our Eastern and Southern Neighbours, COM (2003) 104 final, Brussels, 11 March 2003.

${ }^{26}$ V.A. Chizhov, Remarks at the conference 'Wider Europe: New Agenda' on 'Problems and promises of Wider Europe', Bratislava, 19 March 2004.

${ }^{27}$ I. Ivanov, Interview on Russia's relations with the European Union, Izvestia, 26 February 2004, http://www.mid.ru/en/evropejskij-souz-es/-/asset_publisher/6OiYovt2s4Yc/content/ id/483398 (05.11.2019); V.V. Putin, Press Statement and Answers to Questions by President of the Russian Federation Vladimir Putin at a News Conference Following the Russia-EU Summit, The Hague, 25 November 2004.

28 V.A. Chizhov, Strategicheskoe partnerstvo Rossii I ES: evrokrizis - ne povod dlya peredyshki, «Mezhdunarodnaya Zhizn'» July, 2012.

${ }^{29}$ V.V. Putin, Rossiya I meniauschiysia mir, «Moskovskye Novosti» 27 February 2012.

${ }^{30}$ President of Russia, Foreign Policy Concept of the Russian Federation, Moscow 2008.

${ }^{31}$ S. Lavrov, Russia's Foreign Policy in a Historical Perspective, «Russia in Global Affairs» 2018, Vol. 1, https://eng.globalaffairs.ru/number/Russias-Foreign-Policy-in-a-HistoricalPerspective-19445 (05.11.2019). 
Eventually, this cooperative concept was turned into a rhetorical instrument that was used in the political debate with the West in order to blame the other party for the failure of the cooperation.

The 'New Dividing Lines' concept reflected a conflictual vision of relations between Russia and the West. It was based on a reference to the Cold War when Europe was divided into two political and military alliances. Originally, this concept was addressed to Russia's relations with NATO. It was used to demonstrate Russia's negative attitude to NATO's role in Europe and the prospect of NATO's enlargement in late 1990's, by complaining that NATO tends to ensure security of its member states at the expense of non-NATO countries, whose national interests are undermined and whose security concerns are not taken seriously. Criticiz- ing NATO, Russia tried to promote the active cooperation with the EU, by demonstrating the difference between 'the good West' (the European Union) and 'the bad West' (NATO). That is why until 2014 Russia preferred to avoid mentioning 'dividing lines' when referring to the European Union ${ }^{32}$. On the contrary, Russian officials used to indicate the absence of dividing lines between the EU and Russia as well as the lack of the intention to create new walls dividing Europe ${ }^{33}$. Other concepts, like common spaces and wider Europe, were perceived as methods to prevent creation of new dividing lines ${ }^{34}$. The fact that this 'Cold War' rhetoric is used in reference to the EU constitutes a clear indication of a critical and antagonistic perception of the EU and the lack of trust between Russia and the EU. This concept became an indication of the serious differences between the EU and Russia in terms of their interpretation of their interaction and the roles of both parties. After several years of political conflict, this concept has continued to play a key role in Russia's perception of the EU. The Russian authorities have demonstrated a critical attitude to the West in general and the EU in particular, blaming the West for conflictual relations. For example, Lavrov criticized NATO's expansion towards the Russian borders for provoking systemic problems between Russia and Europe ${ }^{35}$.

32 A. Kazantsev, R. Sawka, New 'Dividing Lines' in Europe: A Crisis of Trust in EuropeanRussian Relations, «Communist and Post-Communist Studies»2012, Vol. 45 (3-4), pp. 289-293.

33 D. Medvedev, Joint Press Conference following the Russia-European Union Summit, Khanty-Mansiysk, 27 June 2008; V.V.Putin, Press Statement and Answers to Questions by President of the Russian Federation Vladimir Putin at a News Conference Following the Russia-EU Summit, The Hague, 25 November 2004.

${ }^{34}$ I. Ivanov, Interview on Russia's relations with the European Union, Izvestia, 26 February 2004, http://www.mid.ru/en/evropejskij-souz-es/-/asset_publisher/6OiYovt2s4Yc/content/ id/483398 (05.11.2019); V.V. Putin, Press Statement and Answers to Questions by President of the Russian Federation Vladimir Putin at a News Conference Following the Russia-EU Summit, The Hague, 25 November 2004.

35 S. Lavrov, Russia's Foreign Policy... 


\section{Conclusion}

In conclusion, an analysis of EU-Russia relations, particularly Russia's transformation through its social interaction with the EU, has demonstrated how Russia's attitude to the EU has been transformed. While at the beginning Russia perceived the EU as a role-model and an important partner, and so supported the strengthening of cooperation and was ready to follow the EU norms and imitate practices, Russia subsequently became disappointed with the EU.

Throughout the process of interaction, the Russian vision of relations with the $\mathrm{EU}$, the EU's role and its own role, have undergone considerable change. For a long time EU-Russia relations were influenced by cooperative concepts: first by the concept of Europeanization, then by the Strategic Partnership concept, followed by the Common Spaces concept and the Wider Europe concept. These cooperative concepts survived various problems and conflicts between the EU and Russia. Only the conflict in Ukraine eventually forced these concepts to make way for the New Dividing Lines concept, and these have come to dominate EU-Russia relations. This political conflict has led to a reconsideration of the Wider Europe concept. This cooperative concept was used as an instrument to blame the West for its non-cooperative behavior and the failure of cooperation project. At the beginning, the EU was perceived as a positive actor, Russia benefitted from the various EU's policies and programs, then the Russian authorities started to criticize the EU's influence, and perceived it as an attempt to confront Russia in the post-Soviet region, and to project its influence there. For Russia, the EU turned from a partner into a competitor. Russia's vision of its own role in the relations with the EU also was transformed. Originally, Russia was not so concerned about the necessity of equal relations, it was ready to follow the European recipes, to agree to the EU norms and regulations, but then Russia started to raise concerns about equal relations with the EU in the framework of Strategic Partnership, and started to lobby for special relations with the EU in the framework of Common Spaces.

In a similar way Russia's attitude to EU norms were also transformed from a positive perception in the early 1990's, when Russia was ready to follow the European experience and imitate the EU norms, to the rather critical approach that is used now, when European practices are criticised. This evolution also reflects Russia's vision of the EU: first, as a role-model and magnet, and today as a competing system of values.

Both social processes (imitation and social learning) indicate a similar tendency that Russia was not satisfied with its interaction with the EU, it was not happy with the role suggested by the EU, its expectations from the EU-Russia relations were different from those of the EU. Finally, imitation and social learn- 
ing has led to a situation when Russia, instead of following the EU norms, started to criticise them, and instead of applying cooperative concepts to its relations with the EU, instead turned to a competitive concept. Constructivism, with its imitation and social learning concepts, helps us to understand transformation of Russia's policy towards the European Union.

\section{Bibliography}

E. Adler, Seizing the Middle Ground: Constructivism, «World Politics in European Journal of International Relation» 1997, Vol. 3.

T. Bordachev, A. Moshes, Russia: End of Europeanization, «Global Affairs» 7 April 2004, http://globalaffairs.ru/number/n_2855 (01.10.2019).

V.A. Chizhov, Strategicheskoe partnerstvo Rossii I ES: evrokrizis - ne povod dlya peredyshki, «Mezhdunarodnaya Zhizn'» July, 2012.

D.A. Danilov, Obshchee prostranstvo vneshnei bezopasnosti Rossii i ES: ambitsii i realnost, «Mirovaya ekonomika i mezhdunarodnye otnosheniya» 2005, Vol. 2.

P.A. Kalinichenko, A.Kh. Mitrokhina, Legal Bases of Mutual Relations Between Russia and the European Union in the Field of Space Exploration, «Aktualnye problemy rossiyskogo prava» 2018, Vol. 90 (5).

S. Karaganov, Russia, Europe and New Challenges, «Sovremennaya Evropa» 2003, Vol. 1 (13).

A. Kazantsev, R. Sawka, New 'Dividing Lines' in Europe: A Crisis of Trust in European- Russian Relations, «Communist and Post-Communist Studies» 2012, Vol. 45 (3-4).

K. Koch, Region-Building and Security: The Multiple Borders of the Baltic Sea Region After EU Enlargement, «Geopolitics» 2015, Vol. 20 (3).

N.B. Kondratieva, Rossiya-ES: Transgranichnoye sotrudnichestvo vne kon'uktury, «Sovremennyaya Evropa» 2014, Vol. 60 (4).

S. Lavrov, Russia's Foreign Policy in a Historical Perspective, «Russia in Global Affairs» 2018, Vol. 1, https://eng.globalaffairs.ru/number/Russias-Foreign-Policy-in-a-HistoricalPerspective-19445 (05.11.2019).

D. Lynch, Russia's strategic partnership with Europe, «Washington Quarterly» 2014, Vol. 27 (2).

I. Pashkovskaya, Energeticheskaya politika Evropeiiskogo Soyuza v otnoshenii Rossii, «Centre of Euro-Atlantic Security: Analytical Reports» 5 (29), Moscow: MGIMO-University 2015.

N.S. Revenko, Sotrudnichestvo mezhdu Rossiei i Evropeiskim soyuzom v voenno-politicheskoi oblasti: sovremennoe sostoyanie $i$ perspektivy razvitiya, [in:] Partnerstvo Rossii $i$ Evropeiskogo soyuza posle rasshireniya: strategicheskoe planirovanie $i$ povsednevnaya realisatsiya, Sankt-Peterburg 2004.

T. Romanova, EU - Russia Energy Cooperation: Major Development Trends and the Present State, «Baltic Region» 2013, Vol. 3.

A. Sergunin, "Vostochnoe partnerstvo" $i$ evropeiskaya bezopasnost, «Evropeiskaya bezopasnost: sobytia, otzenki, prognozy» 2009, Vol. 18.

A.A. Sergunin, V.G. Tikhonov, "Vostochnoe partnerstvo" $i$ rossiyskye interesy na Kavkaze, «Izvestia visshikh uchebnyh zavedeniy. Severo-Kavkazskyi region. Ser. Obschestvennye nauki» 2010, Vol. 4 (158).

A. Wendt, Social Theory of International Politics, Cambridge University Press 2007.

N. Zaslavskaya, The European Union and Russia, [in:] J.-U. Wunderlich, D. Bailey (eds.), The European Union and Global Governance: A Handbook. London and New York, Routledge 2011. 